\title{
Oviductal response to gametes and early embryos in mammals
}

\author{
Veronica Mailloํ, Maria Jesus Sánchez-Calabuig ${ }^{1}$, Ricaurte Lopera-Vasquez ${ }^{1}$, Meriem Hamdi ${ }^{1}$, \\ Alfonso Gutierrez-Adan ${ }^{1}$, Patrick Lonergan ${ }^{2}$ and Dimitrios Rizos ${ }^{1}$ \\ ${ }^{1}$ Departamento de Reproducción Animal, Instituto Nacional de Investigación y Tecnología Agraria y Alimentaria \\ (INIA), Madrid, Spain and ${ }^{2}$ School of Agriculture and Food Science, University College Dublin, Belfield,
}

Dublin 4, Ireland

Correspondence should be addressed to D Rizos; Email: drizos@inia.es

\begin{abstract}
The oviduct is a complex and organized thin tubular structure connecting the ovary with the uterus. It is the site of final sperm capacitation, oocyte fertilization and, in most species, the first 3-4 days of early embryo development. The oviductal epithelium is made up of ciliary and secretory cells responsible for the secretion of proteins and other factors which contribute to the formation of the oviductal fluid. Despite significant research, most of the pathways and oviductal factors implicated in the crosstalk between gametes/early embryo and the oviduct remain unknown. Therefore, studying the oviductal environment is crucial to improve our understanding of the regulatory mechanisms controlling fertilization and embryo development. In vitro systems are a valuable tool to study in vivo pathways and mechanisms, particularly those in the oviducts which in livestock species are challenging to access. In studies of gamete and embryo interaction with the reproductive tract, oviductal epithelial cells, oviductal fluid and microvesicles co-cultured with gametes/embryos represent the most appropriate in vitro models to mimic the physiological conditions in vivo. Reproduction (2016) 152 R127-R141
\end{abstract}

\section{Introduction}

The oviducts (or fallopian tubes, uterine tubes) were described for the first time by the 16th century Italian anatomist, Gabriele Falloppio (1523-1562). However, it was not until a century later when Regnier de Graaf (1641-1673) asserted that the human egg transits through the fallopian tubes. At this time, the fallopian tubes were viewed as 'chimneys enabling the smoke to rise from the matrix into the abdominal cavity' (Alexandre 2001). The oviduct, a seromuscular organ connecting the ovary to the uterus, is the place where life begins in most mammalian species. It is the site of final sperm capacitation, oocyte fertilization and, in most species, the first 3-4 days of embryo development. While embryos can be produced in the absence of exposure to the oviductal environment, it is clear that the oviduct plays an important function in fertilization and early embryo development. Several studies have demonstrated that embryos cultured in the oviducts of sheep (Lazzari et al. 2002, Rizos et al. 2002), cattle (Fair et al. 2001, Tesfaye et al. 2007) or mice (Rizos et al. 2007) are of superior quality than those produced in vitro, in terms of morphology, gene expression, cryotolerance and pregnancy rate after transfer, indicating that the oviduct is not merely an organ through which gametes and embryos transit.
Despite significant research, most of the pathways and oviductal factors implicated in the crosstalk between the gametes/early embryo(s) and the oviduct remain unknown. In this review, we bring together knowledge related to the oviductal response to gametes and the early embryo, and the impact of the oviductal environment on embryo development in vitro.

\section{Anatomy and physiology of the oviduct}

The oviduct is a complex and organized thin tubular structure connecting the ovary with the uterus in which the earliest reproductive events occur. It can be divided into three main regions: the infundibulum, the ampulla and the isthmus (Fig. 1). Histologically, the oviduct contains four distinct cell layers: the outer 'serosa', a single cell layer of squamous (flattened) cells that simply cover the surface; the 'muscularis', usually a double layer of smooth muscle consisting of an outer longitudinal layer and an inner circular layer providing the ability to contract (i.e. transport of secretory products, gametes and early embryo); the 'submucosa', a layer housing blood vessels, nerves and lymphatics; and the 'mucosa', a secretory layer of epithelium lined with a mixture of ciliated and nonciliated simple columnar cells, which produce fluids and also move materials along the 


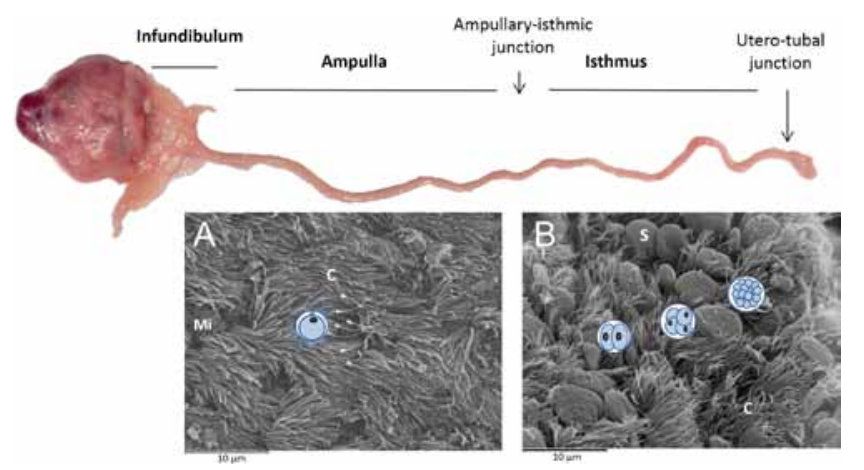

Figure 1 Illustration of the bovine oviduct. Top: Gross anatomy of the oviduct. Bottom: Scanning electron microscopy of the ampulla (A) and isthmus (B) epithelium. Note the difference in cell morphology and population between the two regions. See text for more details. $\mathrm{C}$, cilia; Mi, microvilli; $\mathrm{S}$, secretory cells.

oviduct because of ciliary action (Hunter 1988). At the ovarian extremity, the infundibulum contains finger-like mucosal folds; in the ampulla, the mucosa forms numerous elaborated branched folds, while in the isthmus, the longitudinal folds are less extensive and less branched and the muscle layer is well developed (Abe 1996).

As mentioned above, the oviductal epithelium is made up of ciliary and secretory cells (Fig. 1), the latter responsible for the secretion of proteins and other factors that, together with constituents derived from plasma, contribute to the formation of the oviductal fluid (OF) (Buhi et al. 2000, Leese et al. 2008). The relative proportions of ciliated and secretory cells as well as their morphology change markedly during the oestrous cycle, i.e. under hormonal control. During the follicular phase, there are more ciliated cells in the infundibulum and ampulla while secretory cells predominate during the luteal phase. In contrast, the proportion of secretory and ciliated cells in the isthmus remain similar between the follicular and the luteal phase (Abe 1996).

After ovulation, the fimbria of the infundibulum that surrounds the ovary allows the passage of the ovulated oocyte into the oviduct. At this point, both muscle layers and ciliated cells mechanically guide the oocyte into the lumen of the ampulla (Hunter 1988). During this time, sperm progress in a counter-current fashion from the distal portion of the oviduct, the uterotubal junction, following two different pathways. A small proportion migrate to the ampulla while the vast majority remain in the isthmus, adhered to epithelial cells establishing a sperm reservoir where capacitation is delayed until ovulation occurs (Coy et al. 2012a). Fertilization takes place around the ampullary-isthmic junction (Croxatto 2002) and after that, ciliary activity facilitates zygote transportation through the isthmus (Kölle et al. 2009) until entry into the uterus which occurs at about the 16-cell stage on Day 4 in cattle.

The mammalian oviduct undergoes significant endocrine-induced morphological, biochemical and physiological changes during the oestrous cycle. The processes that take place in the oviduct are dependent on activities of the ciliated and secretory epithelia of the oviduct microenvironment, which are controlled by the ovarian steroids, oestrogen $\left(\mathrm{E}_{2}\right)$ and progesterone $\left(\mathrm{P}_{4}\right)$ (Buhi 2002). Larger preovulatory follicles, associated with greater proestrus $E_{2}$ concentrations and early diestrus $\mathrm{P}_{4}$ concentrations, lead to different oviductal gene expression profiles compared with small preovulatory follicles, which could modify the oviductal environment and impact on embryo development and survival (Gonella-Diaza et al. 2015).

\section{Components of the oviduct contributing to fertilization and early embryo development Epithelial cells}

The epithelial mucosa consists of ciliated and secretory simple columnar epithelial cells (Yániz et al. 2000), the ratio of which is regulated by steroid hormones, facilitating sperm binding and release, capacitation and hyperactivation (Hunter 2008). Epithelial cells are an active site of biosynthesis and secretion of amino acids, energy substances and ions (Hugentobler et al. $2007 a, b, 2008)$. Thus, steroid-regulated epithelial cell secretions can be considered important mediators of the microenvironment that facilitates gamete and zygote health and early development. Winuthayanon and coworkers (2015) demonstrated that conditional knockout mice (cKO) lacking the oestrogen-epithelial receptor $\alpha$ exhibited impaired fertilization due to a reduction in sperm migration and the death of fertilized eggs before the 2-cell stage due to persistence of secreted proteases. This elevated protease activity caused premature degradation of the zona pellucida (ZP) and embryo lysis and wild-type embryos transferred into cKO oviduct failed to develop normally unless rescued by concomitant transfer of protease inhibitors. It was concluded that oestrogen-epithelial receptor $\alpha$ is necessary to suppress oviductal protease activity, which is required for a successful fertilization and preimplantation embryo development (Winuthayanon et al.2015). Epithelial cells also play a role in the transport of the oocyte to the site of fertilization; whereas, during early embryo development, they contribute to creating an optimal environment. Growth factors such as IGFs (insulin-like growth factors), EGF (epidermal growth factor), PDGF (platelet-derived growth factor) and FGFs (fibroblast growth factors) have been implicated in the maternal support of embryonic growth and development (Gandolfi 1995).

Transcriptomic analysis of bovine oviduct epithelial cells have identified different functional groups of genes involved in the regulation of the oviduct during the oestrous cycle (Bauersachs et al. 2004). Cerny and coworkers (2015) identified a large number of 
differentially expressed genes (DEGs) in bovine oviductal epithelial cells between the follicular and luteal phase of the oestrous cycle many of which were exclusive to either the ampulla or the isthmus (a list of differentially expressed genes in the oviduct related with oocyte, sperm and embryo interaction in different species is shown in Table 1). However, the physiological relevance of changes in oviduct physiology during the luteal phase (at Day 12 in those experiments), when gametes or embryos are no longer present, is unclear. Recently, we identified DEGs between the oviductal epithelial cells from the ampulla and isthmus of pregnant heifers collected on Day 3 after oestrus, which may reflect morphological and functional differences between those regions (Maillo et al. 2016). In that study, the main biological processes overrepresented in the ampulla were cell motion, motility and migration, DNA repair, calcium ion homeostasis, carbohydrate biosynthesis and regulation of cilium movement and beat frequency. In the isthmus, synthesis of compounds such as nitrogen, lipids, nucleotides, steroids and cholesterol, as well as vesicle-mediated transport, cell cycle, apoptosis, endocytosis and exocytosis were overrepresented (Maillo et al. 2016). In addition, the co-culture of ampulla cells and cumulus oocyte complexes (COCs) in vitro increased the duration of ZP digestion, the number of penetrated oocytes and monospermic penetration rate compared with isthmus cells and control COCs without oviduct cells (Dadashpour Davachi et al. 2016). Therefore, it seems that the epithelial cells of each part of the oviduct, ampulla and isthmus are specifically prepared to support fertilization and early embryo development.

\section{Oviductal fluid}

Oviductal fluid contains simple and complex carbohydrates, ions, lipids, phospholipids and proteins (Aviles et al. 2010). Some of these components are energy substrates, such as lactate, pyruvate and glucose, as well as amino acids, the concentration of which differs between OF, uterine fluid and serum (Hugentobler et al. 2007a, 2008).

Among the proteins present in OF, glycodelins and lactoferrin are involved in gamete interaction (Ghersevich et al. 2015) and oviductin, osteopontins and the complement protein C3 contribute to early embryo development (Tse et al. 2008). Glycodelins, highly evolutionary conserved proteins, have been detected in the human oviduct at least in four isoforms (glycodelin S, A, F and C) based on the differences in glycosylation (Ghersevich et al. 2015). The use of recombinant glycodelin A was shown to inhibit capacitation of human and hamster sperm (Dutta et al. 2001). Lactoferrin, an oestrogen-regulated glycoprotein, was first identified in human OF. Depending on the sperm capacitation status, this protein exhibited different binding patterns, suggesting its involvement in gamete interaction (Zumoffen et al. 2013). Oviductin, or oviduct-specific glycoprotein (OVGP1), is an oestrus-associated protein that has been demonstrated to be highly conserved in all species studied (Aviles et al. 2010). Analyses of de novo synthesized and secreted proteins from the oviduct epithelia have identified OVPG1 as the major secretory product (Buhi 2002). In pigs and cows, OVGP1 and heparin-like glycosaminoglycans, from the OF, participate in the functional modification of the ZP, which before fertilization makes it more resistant to enzymatic digestion and sperm penetration, contributing to the control of polyspermy (Coy et al. 2008). Moreover, OVGP1 promotes sperm capacitation while maintaining motility and viability (Coy et al. 2012a). Oviductin has been localized in the perivitelline space and the membrane of embryos from different species before implantation, potentially acting as a protective 'shield' around the early embryo (Ghersevich et al. 2015). Embryo culture in the presence of oviductin increased embryo development in vitro in pigs (McCauley et al. 2003) and sheep (Pradeep et al. 2011).

Identification and role of proteins present in the OF is currently the target of many studies because of the potential benefits for in vitro embryo culture. Proteomic analysis of OF have reported significant differences in the protein content between the different phases of the oestrous cycle (Seytanoglu et al. 2008). In that study, seven proteins were highly abundant during the follicular phase (endoplasmin precursor, tumour rejection antigen gp96, ezrin, heat-shock $70 \mathrm{kDa}$ protein 5, calreticulin precursor, actin, cytoplasmic 1 , creatine kinase B-type), while six proteins were highly abundant during the luteal phase (gelsolin precursor, serum albumin precursor, myo-inositol 1-phosphate synthase A1, adenosylhomocysteinase, keratin, type II cytoskeletal 8, keratin, type I cytoskeletal 19) (Seytanoglu et al. 2008). Moreover, the presence of gametes in the oviduct also alters the pattern of protein secretion of the epithelial cells (Georgiou et al. 2007). Such changes in the composition of OF reflect the ability of the oviduct to adapt the environment to the different events from fertilization to early embryo development. Oviductal proteomic changes in different species are shown in Table 2.

\section{Microvesicles}

The role of microvesicles (MVs) as mediators of intercellular communication (Raposo \& Stoorvogel 2013) is based on the transport of proteins, lipids, nucleic acids, ligands and receptors from their cell of origin to a recipient cell (Cocucci et al. 2009). Their potential role in reproduction has been discovered relatively recently. Da Silveira and coworkers (2012) proposed that isolated $\mathrm{MV}$ and exosomes are involved in mediating cell communication within the mammalian ovarian follicle. 


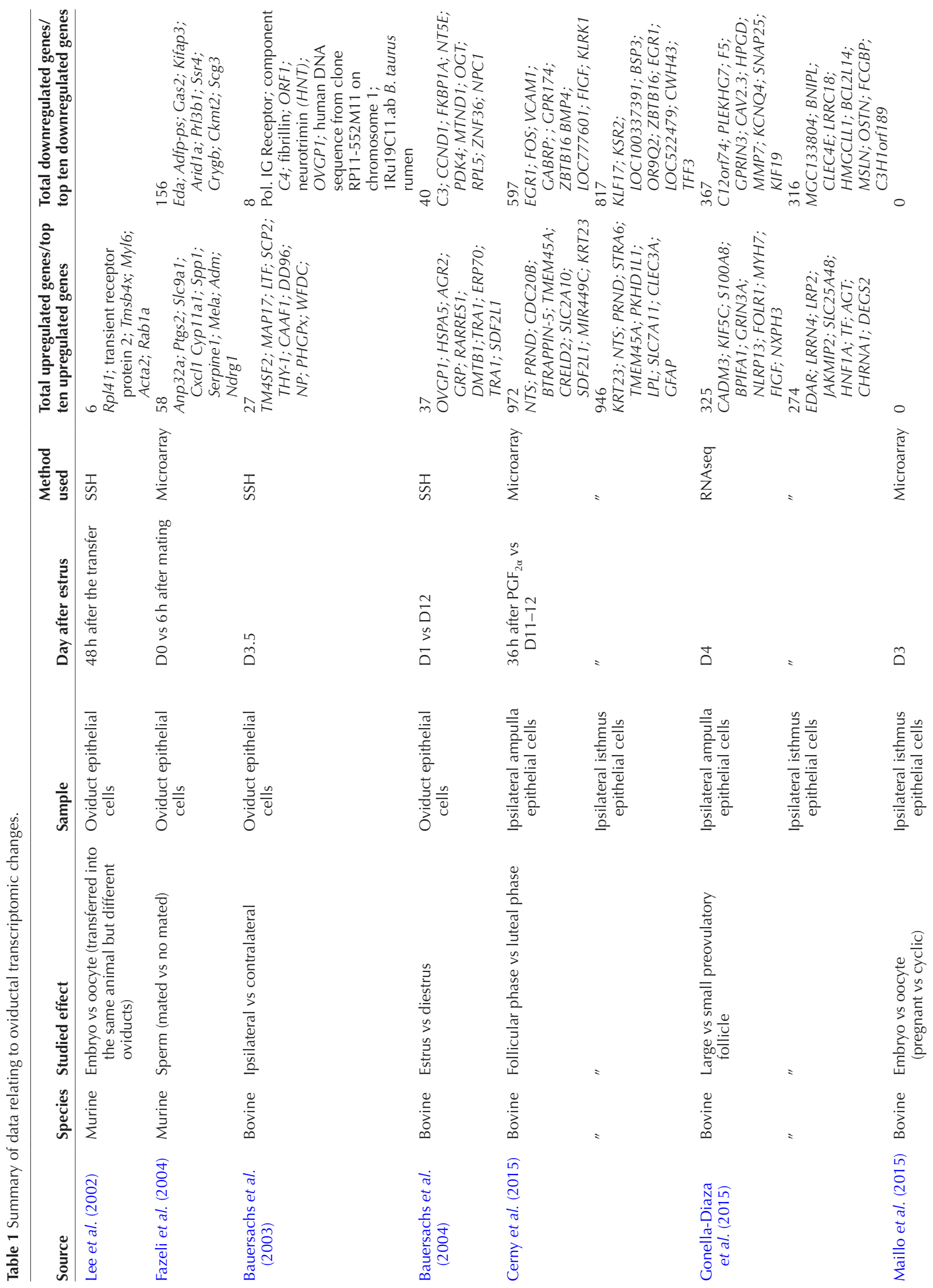



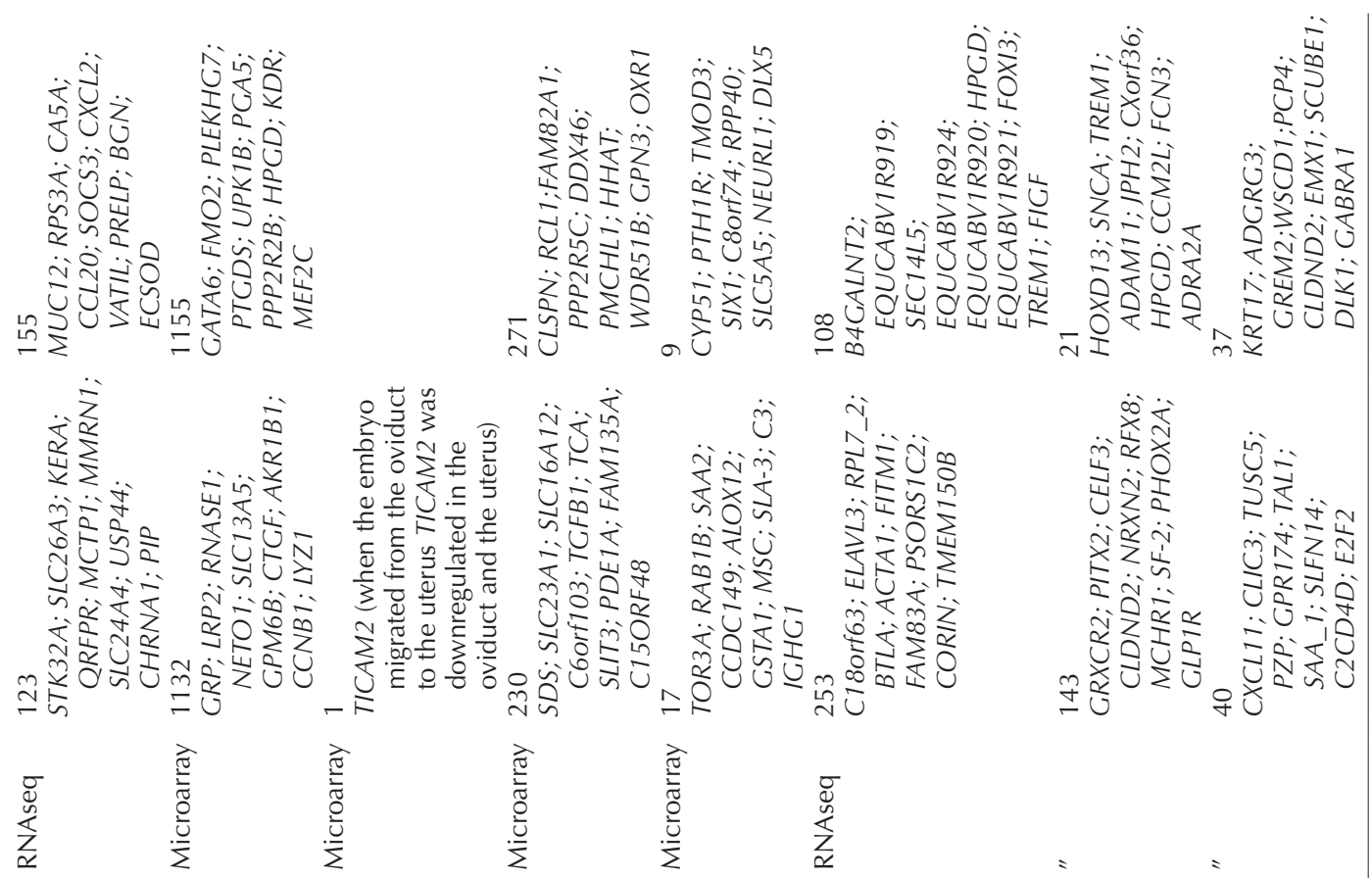

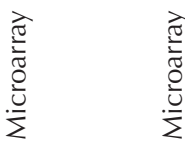

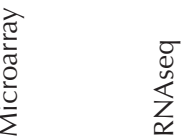

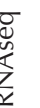
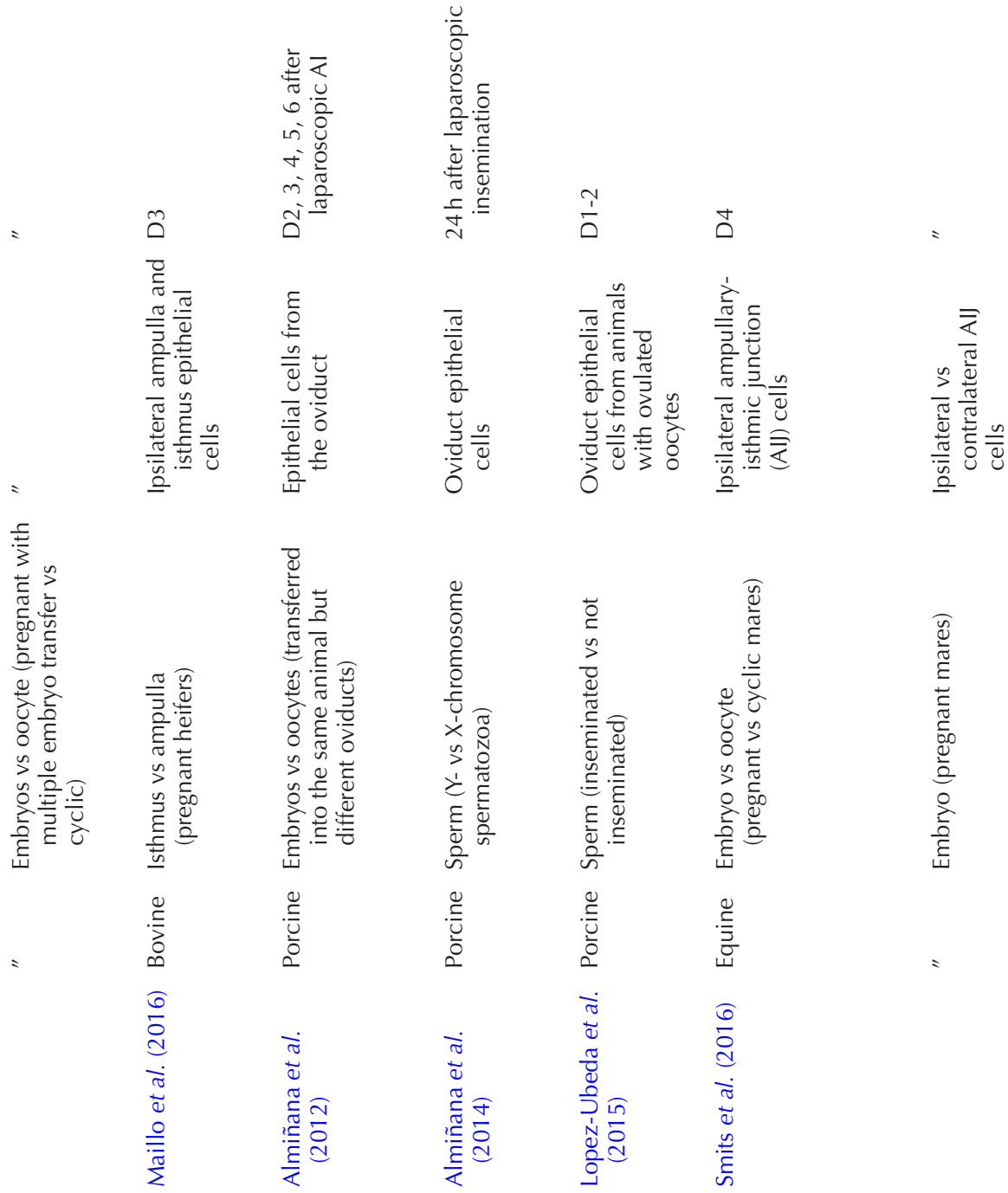


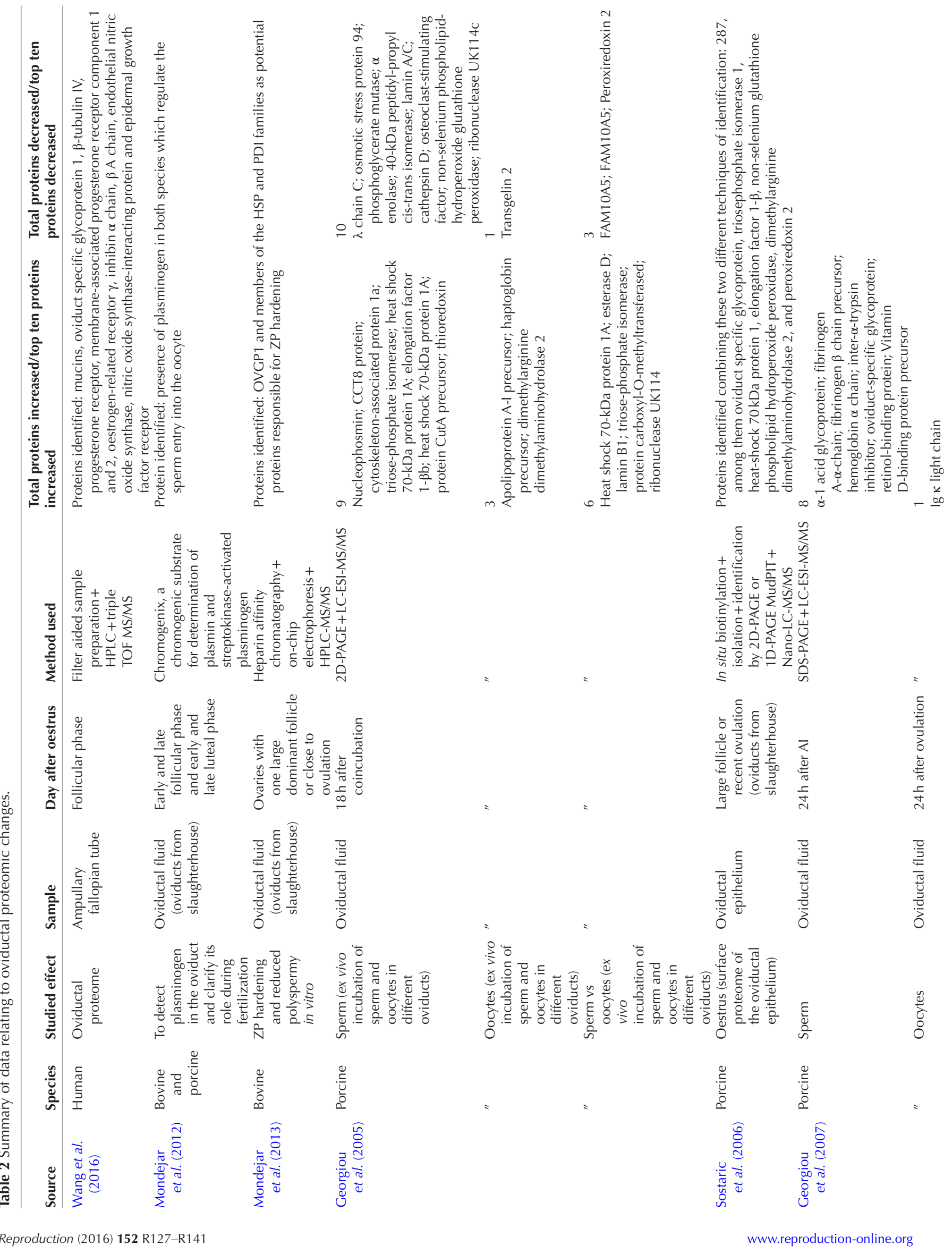




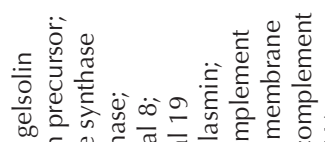

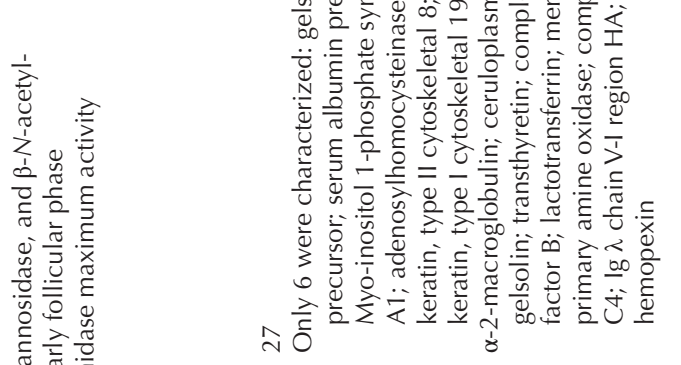

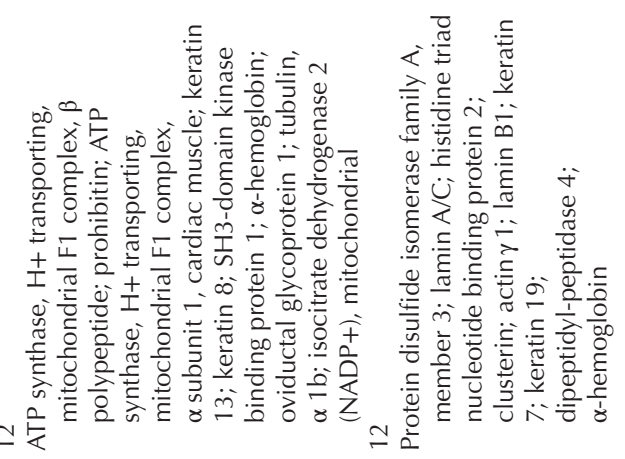

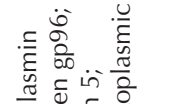

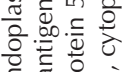

额

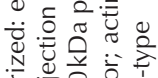

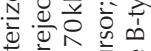

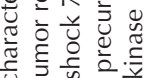

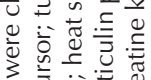

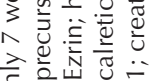
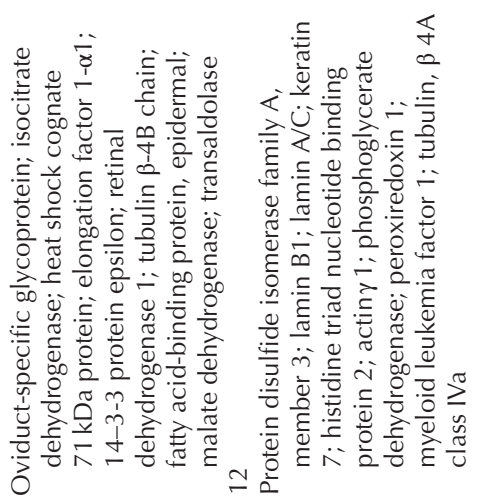

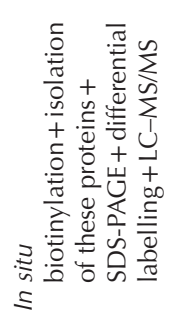

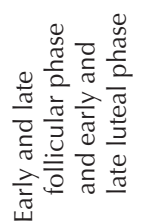

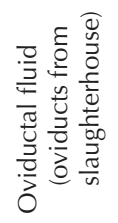

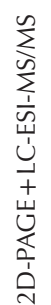
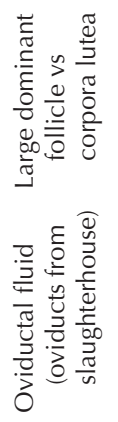

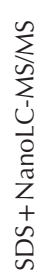

0
0
0
8
0

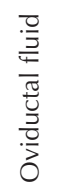

$\frac{\bar{\Xi}}{\frac{\mathbb{S}}{n}}$

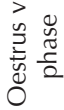

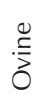

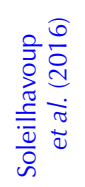

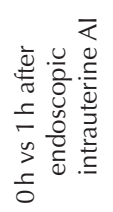

$\overbrace{0}^{\frac{E}{3}}$

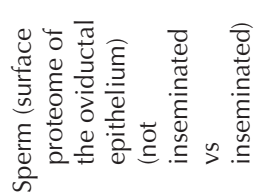

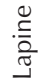

$$
\text { 离 }
$$
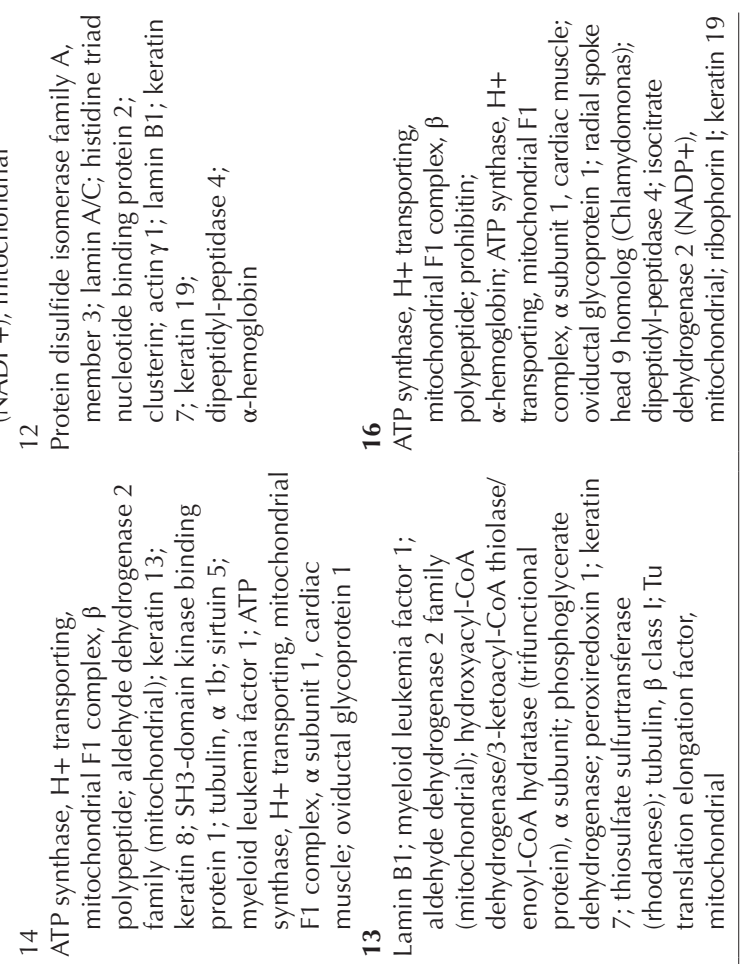

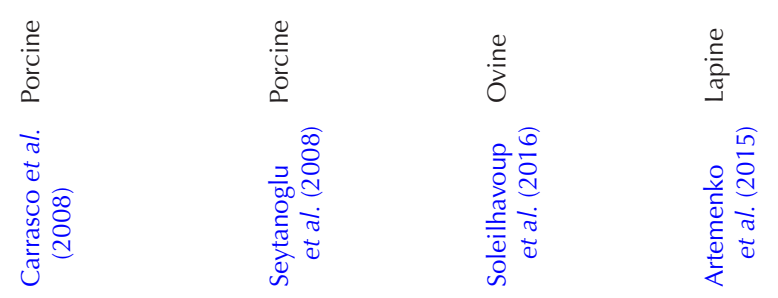

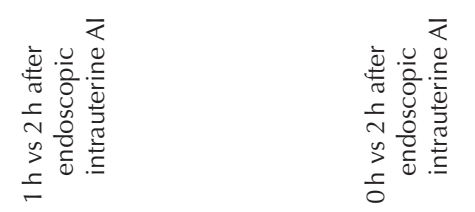

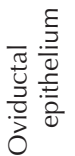

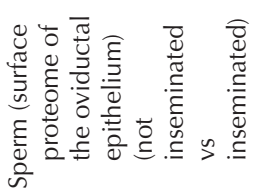


Indeed, the presence of an exosome-mediated transport of miRNAs in the bovine follicle has been already demonstrated (Sohel et al. 2013). Oviductosomes (exosomes and microvesicles present in the oviductal fluid) have been identified in murine and bovine species although studies are needed to determine their interaction with gametes/early embryo(s) (Al-Dossary \& Martin-Deleon 2016). The expression and secretion via oviductal exosomes of PMCA4a ( $\mathrm{Ca}^{2+}$ homeostasis) in female reproductive tissues and luminal fluids during oestrus, and uptake by sperm, suggest possible roles in sperm viability during storage in the oviduct and during capacitation and the acrosome reaction (Al-Dossary et al. 2013).

The study of MV and exosome-specific miRNA in the uterus has enabled the identification of pathways that could be influenced if the exosomes are taken up by trophectoderm or epithelial cells during implantation, or transferred to sperm during transit through the uterus cavity ( $\mathrm{Ng}$ et al. 2013). Recent evidence from Burns and coworkers (2014) indicates that MV present in uterine fluid of pregnant and cyclic ewes contain specific proteins, miRNAs and mRNAs, capable of delivering their content in vitro. Furthermore, in that study, the differences in molecular content by pregnancy status suggested a differential MV source (endometrial epithelia-conceptus trophectoderm) (Burns et al. 2014). This was demonstrated recently by the same group who described extracellular vesicles emanating from both the conceptus trophectoderm and uterine epithelia supporting the notion that MV in uterine fluid have a biological role in conceptus-endometrial interactions, which may be important for the establishment and maintenance of pregnancy (Burns et al. 2016).

\section{Oviductal response to gametes/embryo(s) \\ Oviductal response to sperm}

Physiologically, sperm transiently adhere to the epithelial cells lining of the caudal isthmus (sperm reservoir) and this interaction lengthens the fertile lifespan of sperm, regulates capacitation and also controls the number of sperm present at the site of fertilization to limit the opportunity for polyspermy (Miller 2015). In human and mouse oviducts, presence of sperm increased the expression of adrenomedullin $(A d m)$, a transcript which stimulates ciliary motility (Li et al. 2010). This was also described by Fazeli and coworkers (2004) who reported that the arrival of sperm in the oviduct increased the expression of $A d m$ and prostaglandin endoperoxidase synthase 2 (Ptgs2), involved in smooth muscle contraction/relaxation. Indeed, it seems that $\mathrm{X}$ - and Y-chromosome bearing spermatozoa may elicit a sex-specific transcriptomic response in the oviductal cells; $60-70 \%$ of the genes upregulated in the presence of Y-spermatozoa were related to signal transduction and immune system, compared with the X-spermatozoa (Almiñana et al. 2014). Moreover, Lopez-Ubeda and coworkers (2015) recently showed that the main pathways affected by insemination were related to inflammatory response and immune system, molecular transport, protein trafficking and cell-to-cell signalling (Table 1).

In relation to the oviductal proteome, alterations have been associated with the presence of oocytes or sperm (Table 2). Georgiou and coworkers (2007) showed that although the sperm and the oocyte were able to modulate similar proteins (complement component C3, Ig $\kappa$ variable region and haemoglobin $\beta$ chain), they also had a specific effect on the oviductal proteome. Thus, sperm influenced the expression of 20 proteins (among them $\alpha-1$ acid glycoprotein, fibrinogen $A-\alpha$-chain and fibrinogen $\beta$ chain precursor), whereas the oocyte influenced only one (Ig $\kappa$ light chain). In addition, the protein secretion of complement C3 was increased in the presence of sperm but decreased when the oocyte was present. It is likely that some of these activated genes and secreted proteins play a role in maintaining the viability of sperm while others may be involved in preparing the oviduct for the future embryo (Holt \& Fazeli 2016).

Seminal plasma is a mixture of components originating from male accessory glands which provide nutrients and metabolites, essential for sperm motility, and proteins that modify sperm membrane surface to prevent spontaneous acrosome reaction (Kuo et al. 2016). The role of seminal plasma in successful pregnancy establishment is controversial considering that embryos produced in vitro can establish pregnancy following transfer into recipients not previously exposed to seminal plasma. However, the impact of seminal plasma on embryo development has been addressed in several experiments. Studies in mice show that at conception, seminal fluid elicits molecular and cellular changes in the oviduct and endometrium that directly promote embryo development and implantation competence (Schjenken \& Robertson 2015). In particular, seminal fluid initiates female immune adaptation processes required to tolerate male antigens present in seminal fluid (Robertson et al. 2009). In a very comprehensive study carried out by the same group in mice, it was shown that paternal seminal fluid had an impact on periconception environment through an indirect effect on preimplantation embryos via oviduct expression of embryotrophic cytokines, as well as affected the growth and health of male offspring (Bromfield et al. 2014). Intrauterine infusion of seminal plasma in gilts induced the expression of the cytokines, granulocyte macrophage colony-stimulating factor, interleukin-6 and monocyte chemoattractant protein-1, and the eicosanoid-synthesizing enzyme cyclooxygenase-2, accompanied by altered dynamics in preimplantation embryo development with an increase 
in the number of embryos and their viability ( $\mathrm{O}^{\prime}$ Leary et al. 2004). Furthermore, cows and heifers mounted with a vasectomized bull at oestrus had an increased pregnancy rate following artificial insemination compared with those not mounted (60 vs 35.6\% respectively) (Rodriguez \& Rivera 1999). However, in another study, females exposed to a vasectomized bull or not exposed to a bull had similar pregnancy rates (42.2 vs 49.5\% respectively) (Pfeiffer et al. 2012).

\section{Oviductal response to oocyte(s)}

The oviduct is typically presented with a fully mature oocyte surrounded by an expanded cumulus cell mass that depends on the oviduct to facilitate successful fertilization. According to Hunter (1988), the cilia of the infundibulum move the COC into the oviduct and the spontaneous contraction of the oviduct transport the COC to the site of fertilization. In addition, during its transit through the oviduct, the COC starts to lose the cumulus cells and thereby the ZP becomes more exposed to the OF that prepares the oocyte for fertilization and minimizes polyspermy (Coy et al. 2008, 2012b).

Using a videomicroscopic system, Kölle and coworkers (2009) studied the interaction of gametes/ embryo(s) with the oviduct in an ex vivo model in cows. They observed that when a COC entered the ampulla, it immediately firmly attached to the oviductal epithelium while a degenerated COC floated in the oviductal lumen. After reaching the oviduct, the sperm formed a sperm reservoir in the isthmus bounding their heads to ciliated cells. As soon as a vital COC was in the ampulla, the sperm were hyperactivated, released and went to the ampulla helped by contractions of the oviductal smooth muscles to successfully move against the current caused by ciliary beating. Finally, after fertilization and in the presence of an embryo, the speed of transport was reduced and the vascularization of the oviduct was modified.

\section{Oviductal response to the early embryo(s)}

Some of the earliest evidence demonstrating that the oviduct may have an effect on the embryo comes from investigations carried out in mares, hamsters and rats in the 1960s. In mares, it was found that nonfertilized oocytes were retained in the oviduct (Van Niekerk \& Gerneke 1966) while the fertilized embryos that produced prostaglandin $E_{2}$ were transported to the uterus (Weber et al. 1991). In hamsters, it was shown that embryos were transported to the uterus 1 day earlier than nonfertilized oocytes (Ortiz et al. 1986). In rats, when 1-cell embryos were transferred into the oviducts of recipients, 3 days later, they had reached the morula stage and remained in the oviduct; while when 4-cell embryos were transferred, 3 days later, a significant proportion of those embryos at the blastocyst stage were located in the uterus (Ortiz et al. 1989). It is well known that maternal recognition of pregnancy occurs in the uterus; however, these studies showed that even in the oviduct, the embryo was able to secrete 'a signal' that the mother recognized and to which the oviduct responded specifically according to the presence or not of an embryo.

While more than 30 years have passed since those initial experiments, the oviductal response to the presence of embryos has not been fully elucidated. Lee and coworkers (2002) showed that the presence of embryos in the oviduct upregulated the expression of specific genes in mice like thymosin $\beta 4$, ribosomal protein L41 and nonmuscle myosin light chain 3. In pigs, it was found that most of the newly expressed genes were detected at the 4-cell stage and beyond and three of them were identified as porcine transforming growth factor- $\alpha$, porcine transforming growth factor- $\beta$ binding protein II and porcine astral natriuretic factor receptor-like (Chang et al. 2000). In another study in pigs, Almiñana and coworkers (2012) found that the presence of embryos downregulated the expression of genes related with the immune system. Presumably, any embryo-derived signals would be magnified in litterbearing species compared with mono-ovulatory species which may explain why data demonstrating an effect of the embryo on the oviduct in vivo are scarce (Maillo et al. 2015, Smits et al. 2016). In a recent study from our group, it was necessary to transfer multiple embryos (up to 50) into the oviduct of heifers to detect differences in the transcriptome, while when a single embryo was present in the oviduct (pregnant vs cyclic heifers), no differences were found, suggesting a local effect of the embryo (Maillo et al. 2015). More recently, Smits and coworkers (2016) reported a local influence of the embryo on the transcriptome of the equine oviduct epithelium.

In the studies mentioned above, in cattle, horses and pigs, the presence of an embryo induces subtle changes in the oviductal expression of genes related to immune function. This decrease in the reactivity of the immune system is not that surprising given the semiallogenic nature of the embryo/foetus. Without the appropriate control of the maternal immune system, the embryo will be rejected (Schjenken et al. 2012). However, the semiallogenic foetus that expresses paternal antigens is able to avoid immunological rejection (Billington 2003). In our study in cattle, the genes downregulated were related to: (i) the complement system, which helps to the antibodies and phagocytic cells to clear pathogens; (ii) inflammation, one of the first reactions against a foreign body; and (iii) the major histocompatibility complex, which binds the antigens and present them to $T$ cells (Maillo et al. 2015). In addition, results of immunological studies shown that circulating progesterone blocks the capacity of antigen-presenting cells to present the embryo antigen to Th lymphocytes and creates maternal 
immunological tolerance (Krzymowski \& StefanczykKrzymowska 2012) (Table 1).

\section{In vitro models to study oviduct function}

Studying the oviductal environment is crucial to improving our understanding of the regulatory mechanisms controlling fertilization and embryo development (Aviles et al. 2015). In vitro systems are a valuable tool to study pathways and mechanisms, which are difficult to study in vivo, particularly those in the oviduct in which livestock species are challenging to access (Besenfelder et al. 2012). Nonetheless, while in vitro models provide a simple and defined context to study maternal interactions with gametes and embryos, their advantages are not limited to their simplicity. As Van Soom and coworkers (2010) pointed out, when choosing an in vitro model, the aim of the experiment is an important consideration. In studies of gamete and embryo interaction with the reproductive tract, the use of oviductal epithelial cells, OF and microvesicles may be considered as the most appropriate in vitro models to mimic the physiological conditions pertaining in vivo.

\section{Fertilization models}

Many groups have used in vitro models to study spermoviduct binding (Suarez 2008, Miller 2015). Twodimensional bovine oviduct epithelial cell (BOEC) monolayers have been used to study the role of the oviduct in sperm selection, viability and release (Talevi \& Gualtieri 2010). One criticism of such models is that oviduct epithelial cells lose their cilia in vitro and therefore interpretation of such data from a physiological perspective is challenging. Therefore, other methods have been developed to mimic as close as possible the in vivo conditions. The same research group demonstrated that a three-dimensional culture of the oviductal epithelium is a more reliable model for highly sophisticated and expensive studies aimed to understand the maternal crosstalk with gametes and embryos at the molecular level (Gualtieri et al. 2012). Jordaens and coworkers (2015) compared three different BOEC culture systems: monolayer, explants and monolayers in hanging inserts to keep the cells polarized. More recently, a promising system to mimic the in vivo oviduct epithelial cells niche has been developed consisting of a transwell cell culture combined with $U$-shape inserts that are able to create a tube-like surface, in which bovine oviductal cells can be cultured to confluence and thereafter repolarize (Ferraz et al. 2016).

In relation to OF, Coy and coworkers (2008) demonstrated that preincubation of pig and cow oocytes with periovulatory OF from sows and heifers increased the resistance of the ZP to digestion with pronase (a parameter commonly used to measure the block to polyspermy) and increased the incidence of monospermy after in vitro fertilization.

\section{Embryo development models}

Evolution of techniques using oviduct components for in vitro embryo culture is presented in Fig. 2. BOEC co-culture has been widely used to study early embryonic events (Ulbrich et al. 2010). Embryo co-culture with BOEC has been successfully used since the late 1980s in sheep (Gandolfi \& Moor 1987) and cattle (Eyestone \& First 1989) and later as an in vitro model to identify embryo-maternal signals (Rief et al. 2002). A recent study by Cordova and coworkers (2014) showed that embryo co-culture with BOEC during the first 4 days of embryo development accelerated the kinetics of blastocyst development and improved the expression of genes related with apoptosis and oxidative stress in the developed embryos. Schmaltz-Panneau and coworkers (2014) used BOEC monolayers as in vitro models to demonstrate differences in their gene expression in the presence of bovine blastocysts. In this experiment, those genes upregulated by the presence of the embryos were related with antiviral and immune response (SchmaltzPanneau et al. 2014).

The positive effects of BOEC on embryos are attributed to embryotrophic substances, such as growth factors secreted by the cells (Tse et al. 2008).

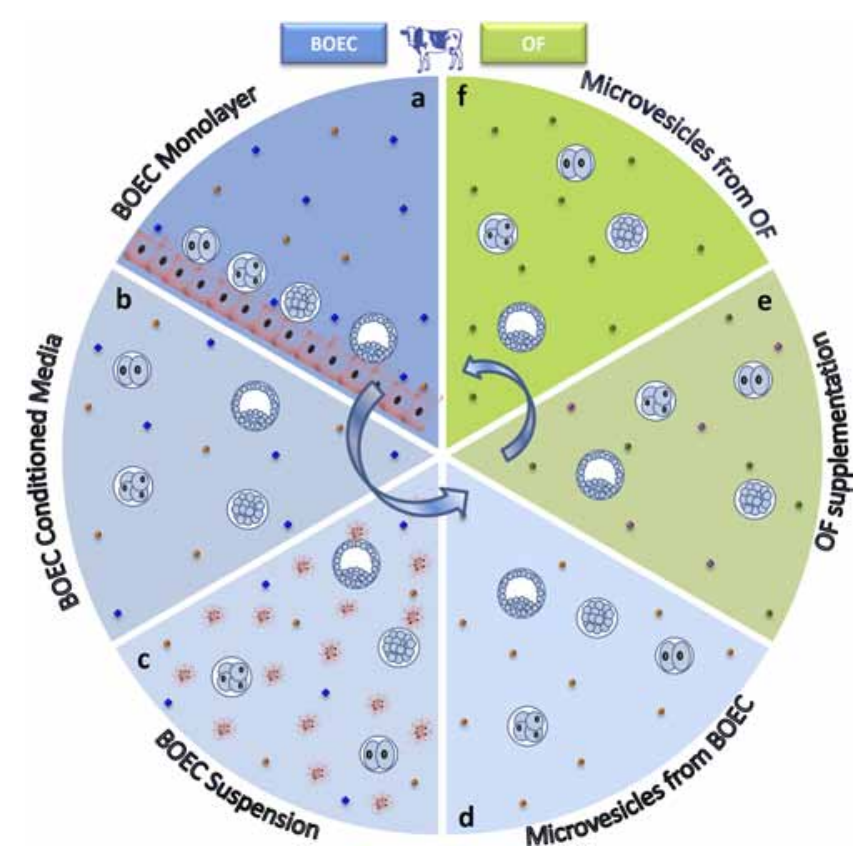

Figure 2 Evolution of techniques for in vitro embryo culture using oviduct components in cattle going anticlock wise. (a) Bovine oviduct epithelial cell (BOEC) monolayer (_); (b) BOEC conditioned media; (c) BOEC suspension ( $)$; (d) microvesicles purified from BOEC conditioned media (•); (e) oviduct fluid (OF) supplementation; (f) microvesicles purified from OF $(\bullet)$. Embryotrophic factors released from BOEC; $\diamond$ Proteins, ions, energy substances from OF. 
However, co-culture systems have been associated with methodological complexity, lack of repeatability and biosanitary risk. Moreover, when cells are cultured in monolayers, they dedifferentiate with the concomitant loss of important morphological characteristics including reduction in cell height, loss of cilia and loss of secretory granules and bulbous protrusions (Ulbrich et al. 2010). An alternative may be the use of BOEC in suspension: nonproliferated BOEC clamps, which remain polarized and viable for longer time than BOEC rapidly proliferating monolayers (Xu et al. 1992). Recently, Yamamoto and coworkers (2014) demonstrated that suspension cells seem to mimic more faithfully in vivo cellular conditions and thereby would be more valuable for studying embryo-maternal interactions. Nevertheless, to avoid primary cultures, established cell lines may constitute an alternative co-culture system by providing a continuous supply of cells that are easily cultured in vitro, cryopreserved and screened for pathogens. We recently reported that an established BOEC line can be used successfully after freezing and thawing, avoiding the lack of reproducibility between replicates, as an in vitro embryo co-culture system and did not differ from BOEC in suspension in terms of embryo development (Lopera-Vasquez et al. 2016a).

An alternative to embryo co-culture with BOEC is the use of their conditioned media (BOEC-CM) (Eyestone \& First 1989). The advantages of BOEC-CM over monolayer co-culture are that no additional cells are required for the culture and the media can be frozen, stored and used when needed (Ramos-lbeas et al. 2014). This would potentially reduce the variation in embryo development often noted in monolayer culture systems. The BOEC-CM is able to support embryo development to the blastocyst stage and improve embryo quality (LoperaVasquez et al. 2016a) through secreted embryotrophic components such as OVGP1 (Briton-Jones et al. 2004), ET-1 (Reinhart et al. 2003), IGF (Xia et al. 1996), VEGF, EGF, IGF1, TGF $\beta 2$ and IL4 (Okada et al. 2005) that have been properly identified.

OF has also been used during in vitro embryo culture in an attempt to mimic the in vivo environment. A short exposure of matured porcine oocytes to bovine OF for $30 \mathrm{~min}$ before fertilization increases the blastocyst rate and quality in terms of morphology, cell number and gene expression patterns of apoptotic and developmentally related genes (Lloyd et al. 2009). In bovine matured oocytes, a short incubation with bovine OF before fertilization did not affect embryo development but altered expression of gene transcripts such as G6PD and SOD32 (Cebrian-Serrano et al. 2013). However, in a recent study, we observed that the culture of bovine zygotes with low concentrations of OF (1.25-0.62\%) increased embryo development and the quality of bovine blastocysts (Lopera-Vasquez et al. 2015). Coy and Yanagimachi (2015) affirmed that the inclusion of reproductive fluids in the human- and animal-assisted reproductive technologies may improve the periconceptional environment for in vitro derived embryos, and improve the efficiency of the current systems for in vitro embryo.

The role of $\mathrm{MV}$ as mediators of intercellular communication between their cell of origin to the recipient cell and their action in reproduction has been described above. However, the effect of these MV on in vitro embryo production is unknown. Saadeldin and coworkers (2015) showed that in vitro derived embryos secrete MV in their conditioned media. Thus, there is a need to investigate the effect of MV on early stages of embryo development in vivo and in vitro. By trying to mimic the intercellular communications between oviductal tissue and embryo in vitro, in a recent study, we provided evidence that MV from conditioned media of an extended culture BOEC monolayer can be isolated, morphologically characterized and successfully used for in vitro embryo culture, improving the quality of the produced blastocysts (Lopera-Vasquez et al. 2016a). Furthermore, research in progress from our group shows also that MV from bovine isthmic OF can be isolated and their supplementation in in vitro embryo culture has a positive effect on the expression patterns of developmental related genes (Lopera-Vasquez et al. 2016b). Future studies on reproductive fluids and their content will identify the molecular mechanisms behind this maternal-embryo communication that affects embryo development and quality in vitro.

\section{Concluding remarks}

While it is possible to fertilize oocytes and grow embryos in vitro in synthetic media, nonetheless, spending time in the oviduct has demonstrable positive effects on the quality of the embryo in terms of morphology, cryotolerance and ability to establish a pregnancy. Despite significant advances in our understanding of early reproductive events, there is still limited evidence for effects of the gametes or embryos on oviduct function (gene expression and protein abundance). However, when one considers the lack of evidence for an effect of the embryo on the uterus up until at least Day 15/16, the time of maternal recognition of pregnancy in cattle, it is not difficult to accept that embryo-induced changes in the oviduct, if any, are probably of limited biological significance. Given the difficulty of study the oviductgametes-embryos(s) interaction in vivo, the challenge is to continue to develop and optimize systems of in vitro culture to maximize embryo quality.

\section{Declaration of interest}

The authors declare that there is no conflict of interest that could be perceived as prejudicing the impartiality of the review. 


\section{Funding}

D R and A G were funded by the Spanish Ministry of Economy and Competitiveness (AGL2012-37510 to D R and AGL201239652-C02-01 to A G). P L was supported by funding from the European Union Seventh Framework Programme FP7/20072013 under grant agreement $\mathrm{n}^{\circ} 312097$ ('FECUND').

\section{References}

Abe H 1996 The mammalian oviductal epithelium: regional variations in cytological and functional aspects of the oviductal secretory cells. Histology and Histopathology 11 743-768.

Al-Dossary AA \& Martin-Deleon PA 2016 Role of exosomes in the reproductive tract Oviductosomes mediate interactions of oviductal secretion with gametes/early embryo. Frontiers in Bioscience 21 1278-1285. (doi:10.2741/4456)

Al-Dossary AA, Strehler EE \& Martin-Deleon PA 2013 Expression and secretion of plasma membrane Ca2+-ATPase 4a (PMCA4a) during murine estrus: association with oviductal exosomes and uptake in sperm. PLOS ONE 8 e80181. (doi:10.1371/journal.pone.0080181)

Alexandre H 2001 A history of mammalian embryological research. International Journal of Developmental Biology 45 457-467.

Almiñana C, Heath PR, Wilkinson S, Sanchez-Osorio J, Cuello C, Parrilla I, Gil MA, Vazquez JL, Vazquez JM, Roca J et al. 2012 Early developing pig embryos mediate their own environment in the maternal tract. PLoS ONE 7 e33625. (doi:10.1371/journal.pone.0033625)

Almiñana C, Caballero I, Heath PR, Maleki-Dizaji S, Parrilla I, Cuello C, Gil MA, Vazquez JL, Vazquez JM, Roca J et al. 2014 The battle of the sexes starts in the oviduct: modulation of oviductal transcriptome by $X$ and Y-bearing spermatozoa. BMC Genomics 15 293. (doi:10.1186/14712164-15-293)

Artemenko K, Horakova J, Steinberger B, Besenfelder U, Brem G, Bergquist J \& Mayrhofer C 2015 A proteomic approach to monitor the dynamic response of the female oviductal epithelial cell surface to male gametes. Journal of Proteomics 113 1-14. (doi:10.1016/j. jprot.2014.09.016)

Aviles M, Gutierrez-Adan A \& Coy P 2010 Oviductal secretions: will they be key factors for the future ARTs? Molecular Human Reproduction $\mathbf{1 6}$ 896-906. (doi:10.1093/molehr/gaq056)

Aviles M, Coy P \& Rizos D 2015 The oviduct: a key organ for the success of early reproductive events. Animal Frontiers 5 25-31. (doi:10.2527/ af.2015-0005)

Bauersachs S, Blum H, Mallok S, Wenigerkind H, Rief S, Prelle K \& Wolf E 2003 Regulation of ipsilateral and contralateral bovine oviduct epithelial cell function in the postovulation period: a transcriptomics approach. Biology of Reproduction 68 1170-1177. (doi:10.1095/ biolreprod.102.010660)

Bauersachs S, Rehfeld S, Ulbrich SE, Mallok S, Prelle K, Wenigerkind H, Einspanier R, Blum H \& Wolf E 2004 Monitoring gene expression changes in bovine oviduct epithelial cells during the oestrous cycle. Journal of Molecular Endocrinology 32 449-466. (doi:10.1677) jme.0.0320449)

Besenfelder U, Havlicek V \& Brem G 2012 Role of the oviduct in early embryo development. Reproduction in Domestic Animals 47 (Supplement 4) 156-163. (doi:10.1111/rda.2012.47.issue-s4)

Billington WD 2003 The immunological problem of pregnancy: 50 years with the hope of progress. A tribute to Peter Medawar. Journal of Reproductive Immunology 60 1-11. (doi:10.1016/S01650378(03)00083-4)

Briton-Jones C, Lok IH, Cheung CK, Chiu TT, Cheung LP \& Haines C 2004 Estradiol regulation of oviductin/oviduct-specific glycoprotein messenger ribonucleic acid expression in human oviduct mucosal cells in vitro. Fertility and Sterility 81 (Supplement 1) 749-756. (doi:10.1016/j. fertnstert.2003.08.016)

Bromfield JJ, Schjenken JE, Chin PY, Care AS, Jasper MJ \& Robertson SA 2014 Maternal tract factors contribute to paternal seminal fluid impact on metabolic phenotype in offspring. PNAS 111 2200-2205. (doi:10.1073/ pnas.1305609111)
Buhi WC 2002 Characterization and biological roles of oviduct-specific, oestrogen-dependent glycoprotein. Reproduction 123 355-362. (doi:10.1530/rep.0.1230355)

Buhi WC, Alvarez IM \& Kouba AJ 2000 Secreted proteins of the oviduct. Cells Tissues Organs 166 165-179. (doi:10.1159/000016731)

Burns G, Brooks K, Wildung M, Navakanitworakul R, Christenson LK \& Spencer TE 2014 Extracellular vesicles in luminal fluid of the ovine uterus. PLoS ONE 9 e90913. (doi:10.1371/journal.pone.0090913)

Burns GW, Brooks KE \& Spencer TE 2016 Extracellular vesicles originate from the conceptus and uterus during early pregnancy in sheep. Biology of Reproduction 94 56. (doi:10.1095/biolreprod.115.134973)

Carrasco LC, Romar R, Aviles M, Gadea J \& Coy P 2008 Determination of glycosidase activity in porcine oviductal fluid at the different phases of the estrous cycle. Reproduction 136 833-842. (doi:10.1530/rep08-0221)

Cebrian-Serrano A, Salvador I, Garcia-Rosello E, Pericuesta E, Perez-Cerezales S, Gutierrez-Adan A, Coy P \& Silvestre MA 2013 Effect of the bovine oviductal fluid on in vitro fertilization, development and gene expression of in vitro-produced bovine blastocysts. Reproduction in Domestic Animals 48 331-338. (doi:10.1111/j.14390531.2012.02157.x)

Cerny KL, Garrett E, Walton AJ, Anderson LH \& Bridges PJ 2015 A transcriptomal analysis of bovine oviductal epithelial cells collected during the follicular phase versus the luteal phase of the estrous cycle. Reproductive Biology and Endocrinology 13 84. (doi:10.1186/s12958015-0077-1)

Chang HS, Cheng WT, Wu HK \& Choo KB 2000 Identification of genes expressed in the epithelium of porcine oviduct containing early embryos at various stages of development. Molecular Reproduction and Development 56 331-335. (doi:10.1002/(ISSN)1098-2795)

Cocucci E, Racchetti G \& Meldolesi J 2009 Shedding microvesicles: artefacts no more. Trends in Cell Biology 19 43-51. (doi:10.1016/j. tcb.2008.11.003)

Cordova A, Perreau C, Uzbekova S, Ponsart C, Locatelli Y \& Mermillod P 2014 Development rate and gene expression of IVP bovine embryos cocultured with bovine oviduct epithelial cells at early or late stage of preimplantation development. Theriogenology 81 1163-1173. (doi:10.1016/j.theriogenology.2014.01.012)

Coy P \& Yanagimachi R 2015 The common and species-specific roles of oviductal proteins in mammalian fertilization and embryo development. Bioscience 65 973-984. (doi:10.1093/biosci/biv119)

Coy P, Cánovas S, Mondéjar I, Saavedra MD, Romar R, Grullón L, Matás C \& Avilés M 2008 Oviduct-specific glycoprotein and heparin modulate sperm-zona pellucida interaction during fertilization and contribute to the control of polyspermy. PNAS 105 15809-15814. (doi:10.1073/ pnas.0804422105)

Coy P, Garcia-Vazquez FA, Visconti PE \& Aviles M 2012a Roles of the oviduct in mammalian fertilization. Reproduction 144 649-660. (doi:10.1530/rep-12-0279)

Coy P, Jimenez-Movilla M, Garcia-Vazquez FA, Mondejar I, Grullon L \& Romar R 2012b Oocytes use the plasminogen-plasmin system to remove supernumerary spermatozoa. Human Reproduction 27 1985-1993. (doi:10.1093/humrep/des146)

Croxatto HB 2002 Physiology of gamete and embryo transport through the fallopian tube. Reproductive BioMedicine Online 4 160-169. (doi:10.1016/S1472-6483(10)61935-9)

da Silveira JC, Veeramachaneni DN, Winger QA, Carnevale EM \& Bouma G) 2012 Cell-secreted vesicles in equine ovarian follicular fluid contain miRNAs and proteins: a possible new form of cell communication within the ovarian follicle. Biology of Reproduction $\mathbf{8 6}$ 71. (doi:10.1095/biolreprod.111.093252)

Dadashpour Davachi N, Zare Shahneh A, Kohram H, Zhandi M, Shamsi H, Hajiyavand AM \& Saadat M 2016 Differential influence of ampullary and isthmic derived epithelial cells on zona pellucida hardening and in vitro fertilization in ovine. Reproductive Biology 16 61-69. (doi:10.1016/j. repbio.2015.11.002)

Dutta B, Ain R, Seshagiri PB \& Karande AA 2001 Differential influence of recombinant non-glycosylated and glycosylated glycodelin on human sperm function: comparative studies with hamster spermatozoa. Reproduction, Fertility and Development 13 111-118. (doi:10.1071/ RD00119) 
Eyestone WH \& First NL 1989 Co-culture of early cattle embryos to the blastocyst stage with oviducal tissue or in conditioned medium. Journal of Reproduction and Fertility 85 715-720. (doi:10.1530/jrf.0.0850715)

Fair T, Lonergan P, Dinnyes A, Cottell DC, Hyttel P, Ward FA \& Boland MP 2001 Ultrastructure of bovine blastocysts following cryopreservation: effect of method of blastocyst production. Molecular Reproduction and Development 58 186-195. (doi:10.1002/(ISSN)1098-2795)

Fazeli A, Affara NA, Hubank M \& Holt WV 2004 Sperm-induced modification of the oviductal gene expression profile after natural insemination in mice. Biology of Reproduction 71 60-65. (doi:10.1095/ biolreprod.103.026815)

Ferraz MAMM, Henning HHW, Van Dorenmalen KMA, Vos PLAM, Stout TAE, Costa PF, Malda J \& Gadella BM 2016 Use of transwell cell culture and 3-dimensional printing technology to develop an in vitro bovine oviduct. Reproduction, Fertility and Development 28156. (doi:10.1071/RDV28N2AB52)

Gandolfi F 1995 Functions of proteins secreted by oviduct epithelial cells. Microscopy Research and Technique 32 1-12. (doi:10.1002/ (ISSN)1097-0029)

Gandolfi F \& Moor RM 1987 Stimulation of early embryonic development in the sheep by co-culture with oviduct epithelial cells. Journal of Reproduction and Fertility 81 23-28. (doi:10.1530/jrf.0.0810023)

Georgiou AS, Sostaric E, Wong CH, Snijders AP, Wright PC, Moore HD \& Fazeli A 2005 Gametes alter the oviductal secretory proteome. Molecular \& Cellular Proteomics 4 1785-1796. (doi:10.1074/mcp. m500119-mcp200)

Georgiou AS, Snijders AP, Sostaric E, Aflatoonian R, Vazquez JL, Vazquez JM, Roca J, Martinez EA, Wright PC \& Fazeli A 2007 Modulation of the oviductal environment by gametes. Journal of Proteome Research 6 4656-4666. (doi:10.1021/pr070349m)

Ghersevich S, Massa E \& Zumoffen C 2015 Oviductal secretion and gamete interaction. Reproduction 149 R1-R14. (doi:10.1530/rep-14-0145)

Gonella-Diaza AM, da Silva Andrade SC, Sponchiado M, Pugliesi G, Mesquita FS, Van Hoeck V, de Francisco Strefezzi R, Gasparin GR, Coutinho LL \& Binelli M 2015 Size of the ovulatory follicle dictates spatial differences in the oviductal transcriptome in cattle. PLOS ONE 10 e0145321. (doi:10.1371/journal.pone.0145321)

Gualtieri R, Mollo V, Braun S, Barbato V, Fiorentino I \& Talevi R 2012 Long-term viability and differentiation of bovine oviductal monolayers: bidimensional versus three-dimensional culture. Theriogenology $\mathbf{7 8}$ 1456-1464. (doi:10.1016/j.theriogenology.2012.06.010)

Holt WV \& Fazeli A 2016 Sperm selection in the female mammalian reproductive tract. Focus on the oviduct: hypotheses, mechanisms, and new opportunities. Theriogenology 85 105-112. (doi:10.1016/j. theriogenology.2015.07.019)

Hugentobler SA, Diskin MG, Leese HJ, Humpherson PG, Watson T, Sreenan JM \& Morris DG 2007a Amino acids in oviduct and uterine fluid and blood plasma during the estrous cycle in the bovine. Molecular Reproduction and Development 74 445-454. (doi:10.1002/mrd.20607)

Hugentobler SA, Morris DG, Sreenan JM \& Diskin MG 2007b lon concentrations in oviduct and uterine fluid and blood serum during the estrous cycle in the bovine. Theriogenology 68 538-548. (doi:10.1016/j. theriogenology.2007.04.049)

Hugentobler SA, Humpherson PG, Leese HJ, Sreenan JM \& Morris DG 2008 Energy substrates in bovine oviduct and uterine fluid and blood plasma during the oestrous cycle. Molecular Reproduction and Development 75 496-503. (doi:10.1002/(ISSN)1098-2795)

Hunter RH 1988 The Fallopian Tubes: Their Role in Fertility and Infertility, p 191. Berlin: Springer Science \& Business Media. (doi:10.1007/978-3642-73045-0_3)

Hunter RH 2008 Sperm release from oviduct epithelial binding is controlled hormonally by peri-ovulatory graafian follicles. Molecular Reproduction and Development 75 167-174. (doi:10.1002/(ISSN)1098-2795)

Jordaens L, Arias-Alvarez M, Pintelon I, Thys S, Valckx S, Dezhkam Y, Bols PE \& Leroy JL 2015 Elevated non-esterified fatty acid concentrations hamper bovine oviductal epithelial cell physiology in three different in vitro culture systems. Theriogenology 84 899-910. (doi:10.1016/j. theriogenology.2015.05.030)

Kölle S, Dubielzig S, Reese S, Wehrend A, König P \& Kummer W 2009 Ciliary transport, gamete interaction, and effects of the early embryo in the oviduct: ex vivo analyses using a new digital videomicroscopic system in the cow. Biology of Reproduction 81 267-274. (doi:10.1095/biolreprod.108.073874)
Krzymowski T \& Stefanczyk-Krzymowska S 2012 Advances in understanding the physiological mechanism of maternal immune tolerance to the embryo. Reproductive Biology 12 265-270. (doi:10.1016/j.repbio.2012.10.004)

Kuo YW, Li SH, Maeda KI, Gadella B \& Tsai PJ 2016 Roles of the reproductive tract in modifications of the sperm membrane surface. Journal of Reproduction and Development. (doi:10.1262/jrd.2016-028)

Lazzari G, Wrenzycki C, Herrmann D, Duchi R, Kruip T, Niemann H \& Galli C 2002 Cellular and molecular deviations in bovine in vitroproduced embryos are related to the large offspring syndrome. Biology of Reproduction 67 767-775. (doi:10.1095/biolreprod.102.004481)

Lee KF, Yao YQ, Kwok KL, Xu JS \& Yeung WS 2002 Early developing embryos affect the gene expression patterns in the mouse oviduct. Biochemical and Biophysical Research Communications 292 564-570. (doi:10.1006/bbrc.2002.6676)

Leese HJ, Hugentobler SA, Gray SM, Morris DG, Sturmey RG, Whitear SL \& Sreenan JM 2008 Female reproductive tract fluids: composition, mechanism of formation and potential role in the developmental origins of health and disease. Reproduction, Fertility and Development 20 1-8. (doi:10.1071/rd07153)

Li HW, Liao SB, Chiu PC, Tam WW, Ho JC, Ng EH, Ho PC, Yeung WS, Tang F \& O WS 2010 Expression of adrenomedullin in human oviduct, its regulation by the hormonal cycle and contact with spermatozoa, and its effect on ciliary beat frequency of the oviductal epithelium. Journal of Clinical Endocrinology and Metabolism 95 E18-E25. (doi:10.1210/ jc.2010-0273)

Lloyd RE, Romar R, Matás C, Gutiérrez-Adán A, Holt WV \& Coy P 2009 Effects of oviductal fluid on the development, quality, and gene expression of porcine blastocysts produced in vitro. Reproduction 137 679-687. (doi:10.1530/REP-08-0405)

Lopez-Ubeda R, Garcia-Vazquez FA, Romar R, Gadea J, Munoz M, Hunter RH \& Coy P 2015 Oviductal transcriptome is modified after insemination during spontaneous ovulation in the sow. PLOS ONE $\mathbf{1 0}$ e0130128. (doi:10.1371/journal.pone.0130128)

Lopera-Vasquez R, Hamdi M, Maillo V, Lloreda V, Coy P, GutierrezAdan A, Bermejo-Alvarez P \& Rizos D 2015 Effect of bovine oviductal fluid on development and quality of bovine embryos produced in vitro. Reproduction, Fertility and Development. (doi:10.1071/RD15238)

Lopera-Vasquez R, Hamdi M, Fernandez-Fuertes B, Maillo V, BeltranBrena P, Calle A, Redruello A, Lopez-Martin S, Gutierrez-Adan A, YanezMo $\mathbf{M}$ et al. 2016a Extracellular vesicles from BOEC in in vitro embryo development and quality. PLOS ONE 11 e0148083. (doi:10.1371/ journal.pone.0148083)

Lopera-Vasquez R, Hamdi M, Maillo V, Nunez C, Yanez-Mo M, Ramirez M, Gutierrez-Adan A, Bermejo-Alvarez P \& Rizos D 2016b Vesicles of bovine oviductal fluid modify the gene expression on bovine in vitro derived embryos. Reproduction, Fertility and Development 28179. (doi:10.1071/rdv28n2ab99)

Maillo V, Gaora PO, Forde N, Besenfelder U, Havlicek V, Burns GW, Spencer TE, Gutierrez-Adan A, Lonergan P \& Rizos D 2015 Oviductembryo interactions in cattle: two-way traffic or a one-way street? Biology of Reproduction 92 144. (doi:10.1095/biolreprod.115.127969)

Maillo V, de Frutos C, O'Gaora P, Forde N, Burns GW, Spencer TE, Gutierrez-Adan A, Lonergan P \& Rizos D 2016 Spatial differences in gene expression in the bovine oviduct. Reproduction 152 37-46. (doi:10.1530/REP-16-0074)

McCauley TC, Buhi WC, Wu GM, Mao J, Caamano JN, Didion BA \& Day BN 2003 Oviduct-specific glycoprotein modulates sperm-zona binding and improves efficiency of porcine fertilization in vitro. Biology of Reproduction 69 828-834. (doi:10.1095/biolreprod.103.016444)

Miller DJ 2015 Regulation of sperm function by oviduct fluid and the epithelium: insight into the role of glycans. Reproduction in Domestic Animals 50 (Supplement 2) 31-39. (doi:10.1111/rda.12570)

Mondejar I, Grullon LA, Garcia-Vazquez FA, Romar R \& Coy P 2012 Fertilization outcome could be regulated by binding of oviductal plasminogen to oocytes and by releasing of plasminogen activators during interplay between gametes. Fertility and Sterility 97 453-461. (doi:10.1016/j.fertnstert.2011.11.032)

Mondejar I, Martinez-Martinez I, Aviles M \& Coy P 2013 Identification of potential oviductal factors responsible for zona pellucida hardening and monospermy during fertilization in mammals. Biology of Reproduction 89 1-8. (doi:10.1095/biolreprod.113.110478) 
Ng YH, Rome S, Jalabert A, Forterre A, Singh $\mathrm{H}$, Hincks CL \& Salamonsen LA 2013 Endometrial exosomes/microvesicles in the uterine microenvironment: a new paradigm for embryo-endometrial cross talk at implantation. PLOS ONE 8 e58502. (doi:10.1371/journal.pone.0058502)

O'Leary S, Jasper MJ, Warnes GM, Armstrong DT \& Robertson SA 2004 Seminal plasma regulates endometrial cytokine expression, leukocyte recruitment and embryo development in the pig. Reproduction $\mathbf{1 2 8}$ 237-247. (doi:10.1530/rep.1.00160)

Okada H, Hirose Y, Manonmani P, Uda A, Ito M \& Sankai T 2005 Characterization of an immortalized oviduct cell line from the cynomolgus monkey (Macaca fascicularis). Journal of Medical Primatology 34 67-72. (doi:10.1111/jmp.2005.34.issue-2)

Ortiz ME, Bedregal P, Carvajal MI \& Croxatto HB 1986 Fertilized and unfertilized ova are transported at different rates by the hamster oviduct. Biology of Reproduction 34 777-781. (doi:10.1095/biolreprod34.4.777)

Ortiz ME, Llados C \& Croxatto HB 1989 Embryos of different ages transferred to the rat oviduct enter the uterus at different times. Biology of Reproduction 41 381-384. (doi:10.1095/biolreprod41.3.381)

Pfeiffer KE, Binversie JA, Rhinehart JD \& Larson JE 2012 Exposure of beef females to the biostimulatory effects of bulls with or without deposition of seminal plasma prior to AI. Animal Reproduction Science 133 27-34. (doi:10.1016/j.anireprosci.2012.06.011)

Pradeep MA, Jagadeesh J, De AK, Kaushik JK, Malakar D, Kumar S, Dang AK, Das SK \& Mohanty AK 2011 Purification, sequence characterization and effect of goat oviduct-specific glycoprotein on in vitro embryo development. Theriogenology 75 1005-1015. (doi:10.1016/j.theriogenology.2010.11.007)

Ramos-Ibeas P, Calle A, Pericuesta E, Laguna-Barraza R, Moros-Mora R, Lopera-Vasquez R, Maillo V, Yanez-Mo M, Gutierrez-Adan A, Rizos D et al. 2014 An efficient system to establish biopsy-derived trophoblastic cell lines from bovine embryos. Biology of Reproduction 9115. (doi:10.1095/biolreprod.114.118430)

Raposo G \& Stoorvogel W 2013 Extracellular vesicles: exosomes, microvesicles, and friends. Journal of Cell Biology 200 373-383. (doi:10.1083/jcb.201211138)

Reinhart KC, Dubey RK, Cometti B, Keller PJ \& Rosselli M 2003 Differential effects of natural and environmental estrogens on endothelin synthesis in bovine oviduct cells. Biology of Reproduction 68 1430-1436. (doi:10.1095/biolreprod.102.006569)

Rief S, Sinowatz F, Stojkovic M, Einspanier R, Wolf E \& Prelle K 2002 Effects of a novel co-culture system on development, metabolism and gene expression of bovine embryos produced in vitro. Reproduction 124 543-556. (doi:10.1530/rep.0.1240543)

Rizos D, Fair T, Papadopoulos S, Boland MP \& Lonergan P 2002 Developmental, qualitative, and ultrastructural differences between ovine and bovine embryos produced in vivo or in vitro. Molecular Reproduction and Development 62 320-327. (doi:10.1002/(ISSN)10982795)

Rizos D, Pintado B, de la Fuente J, Lonergan P \& Gutiérrez-Adán A 2007 Development and pattern of mRNA relative abundance of bovine embryos cultured in the isolated mouse oviduct in organ culture. Molecular Reproduction and Development 74 716-723. (doi:10.1002/ (ISSN)1098-2795)

Robertson SA, Guerin LR, Bromfield JJ, Branson KM, Ahlstrom AC \& Care AS 2009 Seminal fluid drives expansion of the CD4+CD25+ $\mathrm{T}$ regulatory cell pool and induces tolerance to paternal alloantigens in mice. Biology of Reproduction 80 1036-1045. (doi:10.1095/ biolreprod.108.074658)

Rodriguez RO \& Rivera MJ 1999 Fertility of beef cattle females with mating stimuli around insemination. Animal Reproduction Science 54 221-226. (doi:10.1016/S0378-4320(98)00151-1)

Saadeldin IM, Oh HJ \& Lee BC 2015 Embryonic-maternal cross-talk via exosomes: potential implications. Stem Cells Cloning 8 103-107. (doi:10.2147/sccaa.s84991)

Schjenken JE \& Robertson SA 2015 Seminal fluid signalling in the female reproductive tract: implications for reproductive success and offspring health. Advances in Experimental Medicine and Biology 868 127-158. (doi:10.1007/978-3-319-18881-2)

Schjenken JE, Tolosa JM, Paul JW, Clifton VL \& Smith R 2012 Mechanisms of maternal immune tolerance during pregnancy. Recent Advances in Research on the Human Placenta 11 211-242. (doi:10.5772/33541)
Schmaltz-Panneau B, Cordova A, Dhorne-Pollet S, Hennequet-Antier C, Uzbekova S, Martinot E, Doret S, Martin P, Mermillod P \& Locatelli Y 2014 Early bovine embryos regulate oviduct epithelial cell gene expression during in vitro co-culture. Animal Reproduction Science 149 103-116. (doi:10.1016/j.anireprosci.2014.06.022)

Seytanoglu A, Georgiou AS, Sostaric E, Watson PF, Holt WV \& Fazeli A 2008 Oviductal cell proteome alterations during the reproductive cycle in pigs. Journal of Proteome Research 7 2825-2833. (doi:10.1021/ pr8000095)

Smits K, De Coninck DI, Van Nieuwerburgh F, Govaere J, Van Poucke M, Peelman L, Deforce D \& Van Soom A 2016 The equine embryo influences immune-related gene expression in the oviduct. Biology of Reproduction 94 36. (doi:10.1095/biolreprod.115.136432)

Sohel MM, Hoelker M, Noferesti SS, Salilew-Wondim D, Tholen E, Looft C, Rings F, Uddin MJ, Spencer TE, Schellander K et al. 2013 Exosomal and non-exosomal transport of extra-cellular microRNAs in follicular fluid: implications for bovine oocyte developmental competence. PLOS ONE 8 e78505. (doi:10.1371/journal.pone.0078505)

Soleilhavoup C, Riou C, Tsikis G, Labas V, Harichaux G, Kohnke P, Reynaud K, de Graaf SP, Gerard N \& Druart X 2016 Proteomes of the female genital tract during the oestrous cycle. Molecular \& Cellular Proteomics 15 93-108. (doi:10.1074/mcp.M115.052332)

Sostaric E, Georgiou AS, Wong CH, Watson PF, Holt WV \& Fazeli A 2006 Global profiling of surface plasma membrane proteome of oviductal epithelial cells. Journal of Proteome Research 5 3029-3037. (doi:10.1021/pr060366w)

Suarez SS 2008 Regulation of sperm storage and movement in the mammalian oviduct. International Journal of Developmental Biology 52 455-462. (doi:10.1387/ijdb.072527ss)

Talevi R \& Gualtieri R 2010 Molecules involved in sperm-oviduct adhesion and release. Theriogenology 73 796-801. (doi:10.1016/j. theriogenology.2009.07.005)

Tesfaye D, Lonergan P, Hoelker M, Rings F, Nganvongpanit K, Havlicek V, Besenfelder U, Jennen D, Tholen E \& Schellander K 2007 Suppression of connexin 43 and E-cadherin transcripts in in vitro derived bovine embryos following culture in vitro or in vivo in the homologous bovine oviduct. Molecular Reproduction and Development 74 978-988. (doi:10.1002/(ISSN)1098-2795)

Tse PK, Lee YL, Chow WN, Luk JM, Lee KF \& Yeung WS 2008 Preimplantation embryos cooperate with oviductal cells to produce embryotrophic inactivated complement-3b. Endocrinology 149 1268-1276. (doi:10.1210/en.2007-1277)

Ulbrich SE, Zitta K, Hiendleder S \& Wolf E 2010 In vitro systems for intercepting early embryo-maternal cross-talk in the bovine oviduct. Theriogenology 73 802-816. (doi:10.1016/j. theriogenology.2009.09.036)

Van Niekerk CH \& Gerneke WH 1966 Persistence and parthenogentic cleavage of tubal ova in the mare. Onderstepoort Journal of Veterinary Research 33 195-232.

Van Soom A, Vandaele L, Peelman LJ, Goossens K \& Fazeli A 2010 Modeling the interaction of gametes and embryos with the maternal genital tract: from in vivo to in silico. Theriogenology 73 828-837. (doi:10.1016/j.theriogenology.2010.01.001)

Wang C, Liu Y, Chang C, Wu S, Gao J, Zhang Y, Chen Y, Zhong F \& Deng G 2016 Human fallopian tube proteome shows high coverage of mesenchymal stem cells associated proteins. Bioscience Reports $\mathbf{3 6}$ e00297. (doi:10.1042/bsr20150220)

Weber JA, Freeman DA, Vanderwall DK \& Woods GL 1991 Prostaglandin E2 secretion by oviductal transport-stage equine embryos. Biology of Reproduction 45 540-543. (doi:10.1095/biolreprod45.4.540)

Winuthayanon W, Bernhardt ML, Padilla-Banks E, Myers PH, Edin ML, Hewitt SC, Korach KS \& Williams CJ 2015 Oviductal estrogen receptor alpha signaling prevents protease-mediated embryo death. Elife 4 e10453. (doi:10.7554/elife.10453)

Xia P, Han VK, Viuff D, Armstrong DT \& Watson AJ 1996 Expression of insulin-like growth factors in two bovine oviductal cultures employed for embryo co-culture. Journal of Endocrinology 149 41-53. (doi:10.1677/ joe.0.1490041)

Xu KP, Yadav BR, Rorie RW, Plante L, Betteridge KJ \& King WA 1992 Development and viability of bovine embryos derived from oocytes matured and fertilized in vitro and co-cultured with bovine oviducal 
epithelial cells. Journal of Reproduction and Fertility 94 33-43. (doi:10.1530/jrf.0.0940033)

Yamamoto Y, Kobayashi Y \& Okuda K 2014 Purified culture systems for bovine oviductal stromal cells. Journal of Reproduction and Development 60 73-77. (doi:10.1262/jrd.2013-061)

Yániz JL, Lopez-Gatius F, Santolaria P \& Mullins KJ 2000 Study of the functional anatomy of bovine oviductal mucosa. Anatomical Record 260 268-278. (doi:10.1002/(ISSN)1097-0185)

Zumoffen CM, Gil R, Caille AM, Morente C, Munuce MJ \& Ghersevich SA 2013 A protein isolated from human oviductal tissue in vitro secretion, identified as human lactoferrin, interacts with spermatozoa and oocytes and modulates gamete interaction. Human Reproduction $\mathbf{2 8}$ 1297-1308. (doi:10.1093/humrep/det016)

Received 7 March 2016

First decision 1 April 2016

Revised manuscript received 17 June 2016

Accepted 4 July 2016 